\title{
ANALISIS PERBANDINGAN ALGORITMA WARSHALL DAN DIJKSTRAA PADA METODE GVRP DALAM PENENTUAN RUTE TERPENDEK (STUDI KASUS : PT YAKULT CABANG SUMBAWA)
}

\author{
Berry Firmansyah ${ }^{1}$, Koko Hermanto ${ }^{2^{\star}}$ \\ 1,2Program Studi Teknik Industri, Fakultas Teknik Universitas Teknologi Sumbawa \\ ${ }^{*}$ Corresponding Author email: koko.hermanto@uts.ac.id
}

\begin{tabular}{ll}
\hline & Abstrak \\
\cline { 2 - 3 } Diterima : & Yakult merupakan salah satu perusahan industri besar yang bergerak di bidang pembuatan \\
Bulan Januari & susu permentasi. Perusahaan ini memiliki aktivitas usaha yaitu menjual dan \\
2021 & mendistribusikan susu permentasi kepada Toko-toko. Tujuan penelitian ini yaitu \\
& menganalisis perbandingan Algoritma Warshall dan Dijkstraa pada metode GVRP dalam \\
& penentuan rute terpendek. Adapun metode General Vehicle Routing Problem (GVRP) \\
dipakai untuk memudahkan dalam mengelompokan banyak toko (vertek) menjadi \\
Bulan Februari & berbagai kelompok (kluster) sehingga dapat menentukan rute optimal dan biaya yang \\
2021 & minimal. Algoritama Warshall merupakan metode yang memudahkan untuk menentukan \\
& rute terpendek dari semua titik ke semua titik serta memiliki metode yang sederhana dan \\
Keyword: & mudah diimplementasikan. Sementara algoritma Dijkstraa adalah metode untuk mencari \\
Rute terpendek, & jalur terpendek antara 2 titik dari titik awal ke titik tujuan. Dalam penelitian ini dianalisis \\
General Vehicle & bahwa algoritma Warshall dan Dijkstraa untuk penentuan rute terpendek memiliki cara \\
Problem, & perhitungan dan hasil yang hampir sama dengan selisih total jarak 800 meter dengan \\
Algoritma & selisih biaya Rp 645 dalam sekali jalan. Perbedaan rute hanya berada pada kluster 6 dan \\
Warshall, & kluster 9. Kesimpulan penelitian ini menunjukkan bahwa baik Algoritma Warshall dan \\
Algoritma & Algoritma Dijkstraa memiliki cara perhitungan yang hampir sama dengan total jarak dan \\
Dijkstraa & biaya memiliki selisih yang relatif kecil. \\
\hline
\end{tabular}

\section{PENDAHULUAN}

Dalam dunia bisnis, banyak aspek yang mempengaruhi keberhasilan suatu perusahaan dalam bertahan dan bersaing yaitu di bidang pemasaran, produksi serta proses sistem distribusi. Salah satu aspek yang mempengaruhi keberhasilan pada perusahaan adalah sistem transportasi dan distribusi. Transportasi dan distribusi merupakan dua komponen yang selalu mempengaruhi keunggulan kompotitif suatu perusahaan karena penurunan biaya tansportasi dapat meningkatkan keuntungan perusahaan secara tidak langsung.

Ada berbagai macam perusahaan industri yang ada di kabupaten Sumbawa, salah satunya perusahaan susu permentasi yaitu Yakult. Yakult merupakan salah satu perusahan industri besar yang bergerak di bidang pembuatan susu permentasi. Perusahaan ini memiliki aktivitas usaha yaitu menjual dan mendistribusikan susu permentasi kepada toko-toko dalam kegiatan operasional usahanya. Salah satu kantor cabang berada di Kabupaten Sumbawa dengan wilayah distribusi meliputi daerah-daerah sekitar Sumbawa.

Oleh karena itu, diperlukan strategi yang tepat yang diperlukan untuk menekan biaya rute distribusi seminimal mungkin. Dalam mendistribusikan produk ke berbagai daerah tentunya membutuhkan biaya transportasi yang tidak sedikit jumlahnya.
Mengetahui akan pentingnya proses pendistribusian yang tepat, maka penelitian ini dilakukan untuk membandingkan berbagai metode terhadap rute distribusi pada perusahaan Yakult dalam mencari solusi agar biaya distribusi menjadi optimal. Dari latar belakang tersebut, maka penulis menggunakan metode General Vehicle Routing Problem (GVRP), Algoritma Warshall dan Algoritma Dijkstraa untuk mengolah data dan mencari rute terpendek. Karena pada metode ini memiliki kelebihan yaitu: menurut Petrica (2011) metode GVRP memudahkan dalam mengelompokan banyak toko (vertek) menjadi berbagai kelompok (kluster) agar memudahkan dalam menentukan rute optimal dan biaya yang minimal. Algoritama Warshall adalah metode yang memudahkan menentukan rute terpendek dari semua titik ke semua titik serta memiliki metode yang sederhana dan mudah diimplementasikan. Sementara Algoritma Dijkstraa digunakan untuk mencari jalur terpendek antara 2 titik dari titik awal ke titik tujuan (Jong Jek Siang, 2014).

Beberapa penelitian tentang model general vehicle routing problem (GVRP) dengan metode Djikstra dalam pengaplikasiannya dalam kehidupan sehari-hari, seperti yang penah diaplikasikan oleh Hermanto \& Ermayanti (2019) dan Gautama \& Hermanto (2020) pada penentuan rute terpendek bus sekolah. Selain itu juga aplikasi model GVRP dapat 
digunakan dalam menentukan rute terpendek pendistribusian sampah yang pernah dilakukan oleh Hermanto \& Ruskartina (2018) dan Hermanto \& Ruskartina (2018b) serta dapat juga diaplikan dalam penentuan rute terpendek pendistribusian gas LPG seperti yang dilakukan oleh Hermanto et al (2020).

\section{LANDASAN TEORI}

\section{Teori Graf}

Graf adalah objek abstrak matematis, yang mana mengandung vertek dan edge. Edge menghubungkan sepasang vertek. Di sepanjang edge yang ada pada graf memungkinkan bergerak dari satu vertek ke vertek lainnya. Tergantung pada apakah atau tidak seseorang dapat berjalan di sepanjang edge oleh kedua sisi atau hanya satu sisi tergantung graf tersebut merupakan directed graf atau undirected graf (Magzhan \& Jani, 2013).

\section{General Vehicle Routing Problem (GVRP)}

Penggunaan GVRP dimaksudkan untuk mencari rute terpendek yang direpresentasikan dengan sebuah graf berarah $G=(V, A)$ dengan $V=$ $\{1,2,3, \ldots . . n\}$ sebagai himpunan vertek dan $A=\{(i, j) \mid i, j \in V, i \neq j\}$ himpunan edge. Nilai $c_{i j}$ tidak bernilai negatif untuk setiap edge $(i, j) \in A$, himpunan vertek dibagi menjadi $\mathrm{k}+1$ himpunan bagian tak kosong saling esklusif, yang disebut dengan kluster $V_{0}, V_{1}, V_{2}, \ldots \ldots . V_{k}\left(V=V_{0} \cup V_{l} \cup \ldots U\right.$ $V_{k}$ dan $V_{l} \cap V_{p}=\varnothing$ untuk semua $l, p \in\{0, l, \ldots k\}$ dan $l \neq p$. Kluster $\mathrm{V}_{0}$ hanya memiliki satu vertek 0 , yang mewakili depot dan $\mathrm{n}$ sisa vertek-verteknya terbagi menjadi k kluster, yang mewakili konsumen yang tersebar secara geografis (Petrica C. Pop dan Andrei Horvat-Marc, 2012). Ilustrasi GVRP dan solusi layak yang merupakan lanjutan dari masalah GVRP, yang dapat dilihat pada Gambar 1 .

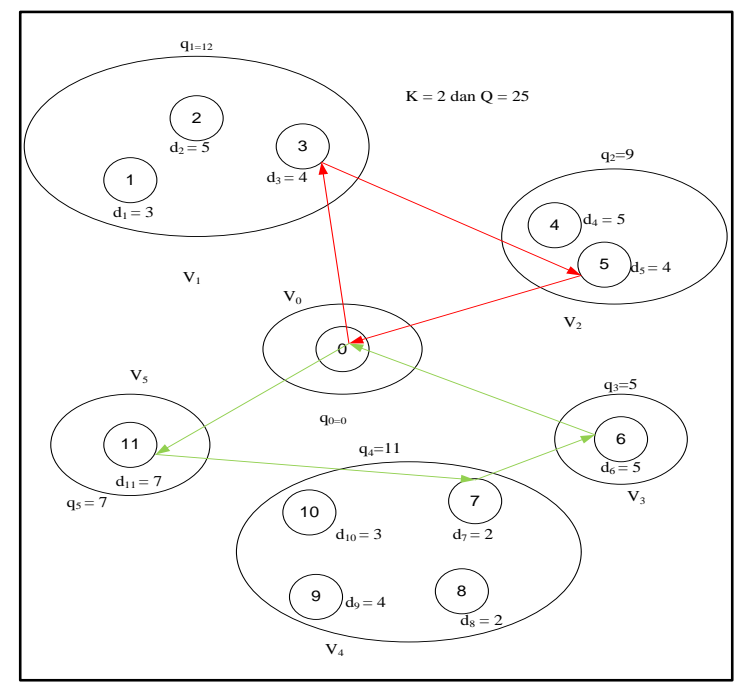

Gambar 1. Contoh solusi layak GVRP

Sumber : Hermanto, 2015.

\section{Algoritma Warshall}

Algoritma Warshall merupakan algoritma yang lebih efisien untuk mencari jarak terpendek dari semua titik ke semua titik. Algoritma warshall untuk mecari path terpendek merupakan algoritma yang sederhana dan mudah implementasinya. Prinsip dasarnya tidak jauh berbeda dengan algoritma Dijkstraa. Pada iterasi ke-1, dihitung jarak terpendek dari semua titik ke semua titik apabila path-nya melalui titik $V_{i}$.

Algoritma warshall untuk mecari path terpendek adalah sebagai berikut :

1. $W=W^{(0)}$

2. Untuk $\mathrm{k}=1$ hingga $\mathrm{n}$, lakukan: \{pengujian jarak lewat titik $V_{k}$ \}

Untuk I = 1 hingga $\mathrm{n}$, lakukan:

Untuk $\mathrm{j}=1$ hingga $\mathrm{n}$ lakukan:

Jika $W_{i j}>W_{i, k}>W_{k j}$ maka tukar $W_{i j}$ dengan $W_{i, k}+W_{k j}$

3. $W^{*}=W$

\section{Algoritma Dijkstraa}

Algoritma Dijkstraa ditemukan oleh Edsger Dijkstraa pada tahun 1959, adalah algoritma pencarian graf yang memecahkan masalah jalur terpendek yang bersumber dari satu vertek untuk sebuah graf dengan bobot vertek tidak boleh negatif (Asti, 2013). Analisis dilakukan dengan cara memeriksa vertek dengan bobot terkecil dan memasukkannya ke dalam himpunan solusi dengan awal pencarian vertek asal membutuhkan pengetahuan tentang semua jalur dan bobotnya, sehingga dibutuhkan pertukaran informasi dengan semua vertek.

\section{METODE PENELITIAN}

Analisis terhadap hasil pengolahan data untuk analisis perbandingan Algoritma Warshall dan Dijkstraa pada Generalized Vehicle Routing Problem (GVRP) dalam penentuan rute terpendek, maka perlu di lakukan sebagai berikut :

1. Data yang sudah dikumpulkan langsung diolah menggunakan metode GVRP dan Algoritma Warshall :

a. Memodelkan dalam bentuk graf yaitu model GVRP

b. Gunakan Algoritma Warshall untuk menyusun model CGVRP dari studi kasus

2. Menganalisis perbandingan rute usulan berupa contoh penerapan beberapa metode dalam menentukan rute terpendek terhadap rute distribusi Yakult dalam kota sumbawa. 


\section{HASIL DAN PEMBAHASAN}

\section{Deskripsi Masalah}

Depot atau gudang Yakult beralamat $\mathrm{Jl}$. Labu Punti, Karang Dima, Labuhan Badas, Kabupaten Sumbawa, Nusa Tenggara Barat dan terletak pada posisi geografis $8^{\circ} 28^{\prime} 06.8^{\prime \prime S}$ $117^{\circ} 22^{\prime} 40.1$ "E, merupakan perusahaan yang bergerak dalam pembuatan dan pengiriman susu fermentasi. Proses pendistribusian dilakukan dengan mengirimkan Yakult ke toko-toko langganan. Pendistribusian yakult di kota Sumbawa menggunakan 1 kendaraan mobil box yang menempuh $8 \mathrm{~km}$ meter per liter dengan kapasitas menghitung total jarak dibagi jarak tempuh per liter dikali dengan harga bensin. Jarak setiap terminal ditentukan menggunakan google maps dengan tetap memperhatikan jarak yang sebenarnya.

\section{Simulasi Penyelesaian kasus Model GVRP}

Setiap toko tujuan dikelompokan berdasarkan masing-masing kelurahan. Kelurahan definisikan sebagai kluster, kluster disusun berdasarkan jarak terdekat dari depot sedangkan toko definisikan sebagai vertek. Pengelompokkan tetap memperhatikan kapasitas kendaraan dan bila melebihi kapasistas harus menggunakan kendaraan lain. Jumlah toko dan pengelompokkan sesuai

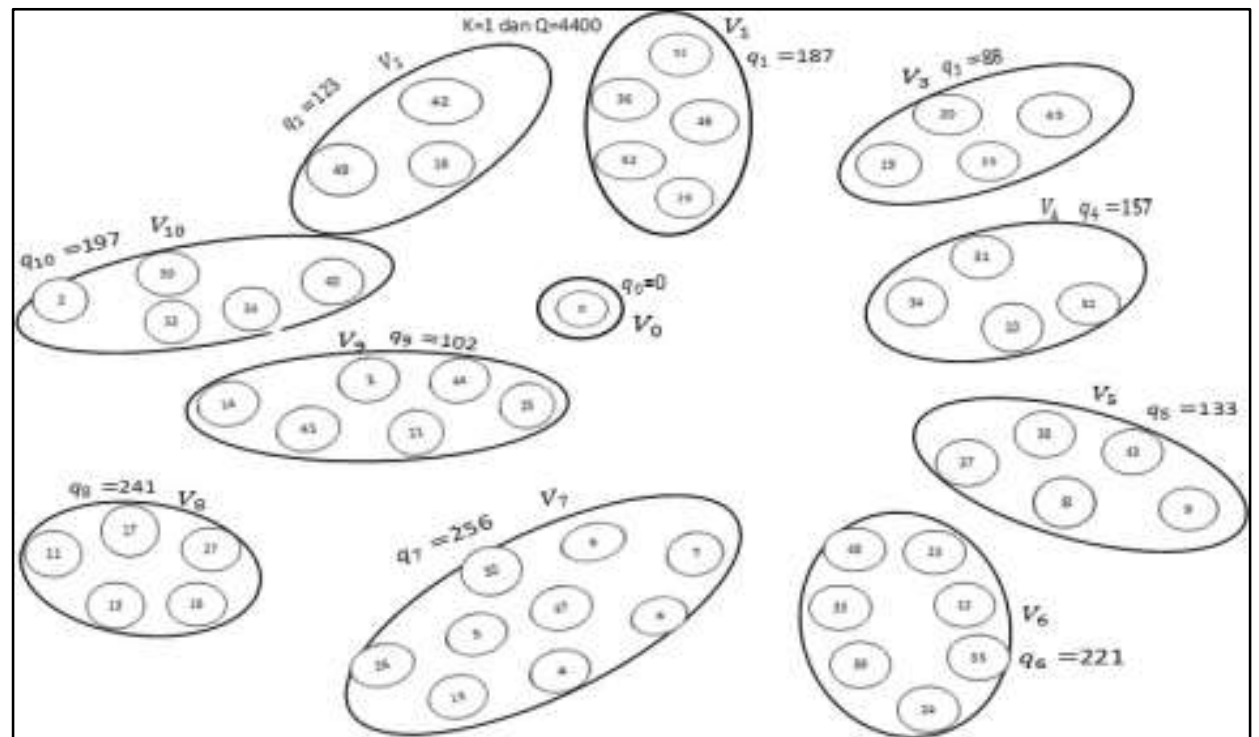

muatan 4400 pack yakult yang berbahan bakar bensin dengan harga bensin $\mathrm{Rp} 6.450$ pada tahun 2019. Perhitungan biaya didapatkan dengan cara kelurahan. Dapat diilustrasikan lokasi dan pengelompok pada gambar seperti Gambar 2 berikut:

Gambar 2. Pengelompokkan toko

Berdasarkan Gambar 2 setelah dikelompokan selanjutnya dimodelkan rute GVRP yaitu langkah pertama menentukan satu titik tujuan dari vertek 0 ke semua vertek yang ada dan yang memiliki jarak terdekat dengan vertek 0 dan diperoleh vertek terdekat yaitu vertek 29 yang mewakili kluster 1, langkah kedua menentukan satu titik akhir dari semua vertek yang ada ke vertek 0 dan yang memiliki jarak terdekat dengan vertek 0 kecuali kluster 1 karena sudah dipilih dan diperoleh vertek terdekat yaitu vertek 16 yang mewakili kluster 2. Langkah ketiga menentukan titik tujuan dari vertek 29 ke semua vertek kecuali kluster yang telah terpilih dan diproleh vertek terdekat yaitu vertek 19 yang mewakili kluster 3 dan seterusnya dilakukan dengan langkah yang sama. Setelah semua kluster mempunyai masing-masing titik awal yang telah dipilih sehingga pemodelan GVRP di ilustrasikan pada gambar 3 .

\section{Menentukan rute terpendek menggunakan Algoritma Warshall}

Perhitungan solusi optimal menggunakan model CGVRP dan Algoritma Warshall dari model GVRP:

a. Penyelesaian pada kluster 1 Berdasarkan model GVRP diatas sudah dipilih titik awal pada kluster 1 yaitu vertek 29 .

$\mathrm{i}=v_{29}, v_{36}, v_{46}, v_{51}, v_{52}$

$\mathrm{j}=v_{29}, v_{36}, v_{46}, v_{51}, v_{52}$

\begin{tabular}{|c|c|c|c|c|c|}
\hline & $v_{29}$ & $v_{36}$ & $v_{46}$ & $v_{51}$ & $v_{52}$ \\
\hline \multirow{5}{*}{$\mathrm{W}=$} & {$[\infty$} & 1900 & 1000 & 4500 & $350]$ \\
\hline & 1900 & $\infty$ & 900 & 4100 & 1600 \\
\hline & 1000 & 900 & $\infty$ & 3500 & 650 \\
\hline & 4500 & 4100 & 3500 & $\infty$ & 3700 \\
\hline & L 350 & 1600 & 650 & 3700 & $\infty$ \\
\hline
\end{tabular}




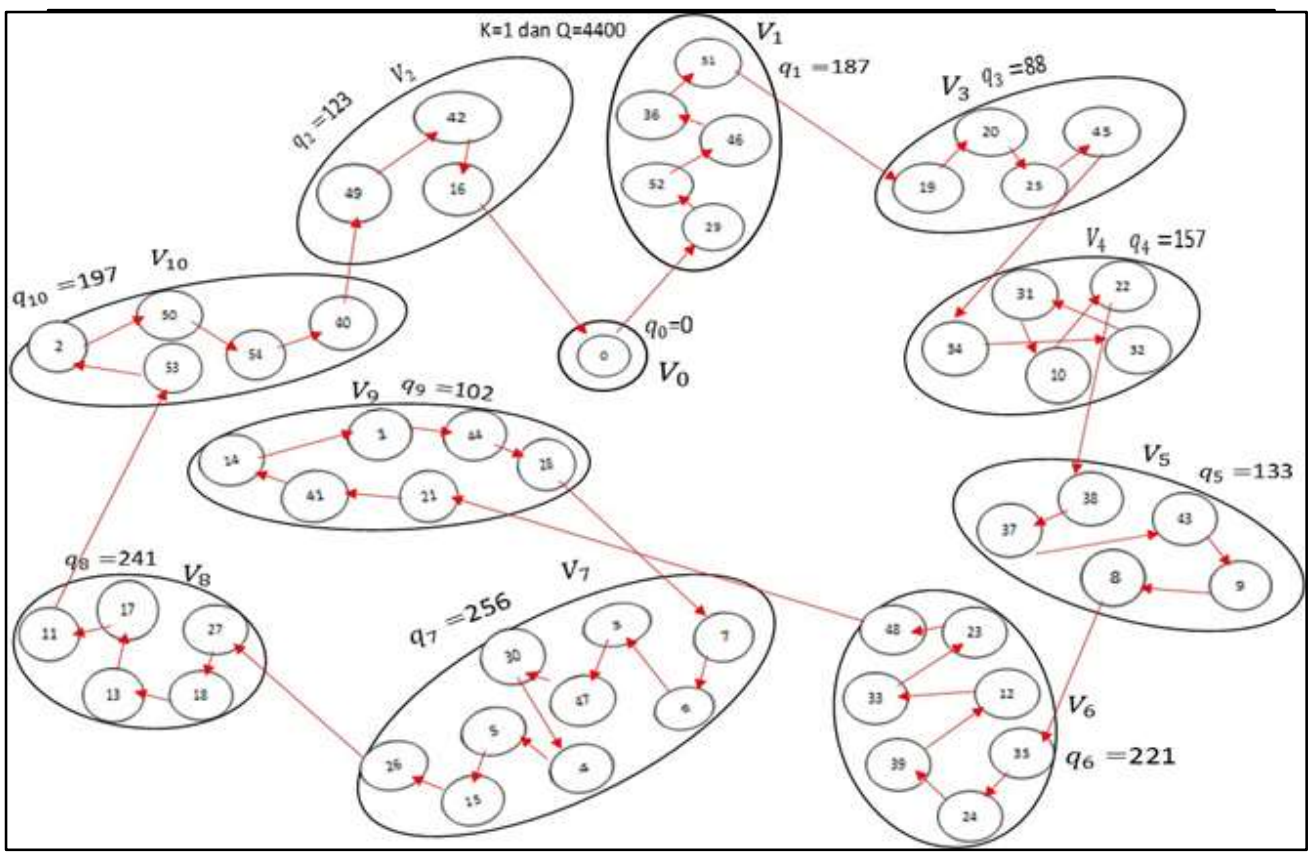

Gambar 3 Model GVRP

Dari matriks diatas langkah selanjutnya pada perhitungan Algoritma Warshall yaitu melakukan iterasi untuk mencari jarak terdekat untuk setiap vertek, karena jarak terdekat setiap vertek sudah ada maka tidak perlu lagi melakukan iterasi. Selanjutnya untuk mencari rute teroptimal yang melalui semua vertek dengan menggunakan matrik $\mathrm{Z}$. Matrik $\mathrm{Z}$ berfungsi untuk menentukan titik tujuan dari vertek awal dengan memilih jarak yang paling kecil dari vertek yang ada kecuali yang sudah terpih.

$$
\begin{array}{lllll}
v_{29} & v_{36} & v_{46} & v_{51} & v_{52}
\end{array}
$$

$\mathrm{Z}=\left[\begin{array}{l}v_{29} \\ v_{36} \\ v_{46} \\ v_{51} \\ v_{52}\end{array}\left[\begin{array}{lllll}v_{52} & v_{52} & v_{52} & v_{52} & v_{52} \\ v_{51} & v_{51} & v_{51} & v_{51} & v_{51} \\ v_{36} & v_{36} & v_{36} & v_{36} & v_{36} \\ v_{46} & v_{46} & v_{46} & v_{46} & v_{46} \\ v_{46} & v_{46} & v_{46} & v_{46} & v_{46}\end{array}\right]\right.$

Berdasarkan matrik $\mathrm{Z}$ diketahui rute terpendek $v_{29}-v_{52}-v_{46}-v_{36}-v_{51}$ dengan total jarak 6000 meter.

Setelah melakukan perhitungan dengan cara yang sama pada semua kluster didapatkan data dari perhitungan masing-masing kluster dengan menggunakan GVRP setelah itu mengunakan model CGVRP dalam menghitung didalam kluster dan untuk menentukan urutan vertek yang dilalui didalam kluster menggunakan Algoritma Warshall didapatkan keselurahan rute terpendek yang digunakan dalam pendistribusian. Dengan rute terpendek sebagai berikut:

$$
\begin{aligned}
& v_{0}-v_{29^{-}}-v_{52^{-}}-v_{46^{-}}-v_{36^{-}}-v_{51^{-}}-v_{19^{-}}-v_{20^{-}}-v_{25^{-}}-v_{45^{-}}-v_{34^{-}} \\
& v_{32}-v_{31}-v_{10}-v_{22}-v_{38}-v_{37}-v_{43}-v_{9}-v_{8}-v_{35}-v_{24}- \\
& v_{39}-v_{12}-v_{33}-v_{23}-v_{48}-v_{21}-v_{41}-v_{14}-v_{1}-v_{44^{-}}-v_{28^{-}} \\
& v_{7}-v_{6}-v_{3}-v_{47}-v_{30}-v_{4}-v_{5}-v_{15}-v_{26}- \\
& v_{27}, v_{18}, v_{13}, v_{17}, v_{11}-v_{53}-v_{2}-v_{50^{-}}-v_{54}-v_{40^{-}}-v_{49^{-}} \\
& v_{42}-v_{16}-v_{0} \text { dengan total jarak sebesar } 49400 \text { meter. } \\
& \text { Dari hasil perhitungan rute terpendek dapat }
\end{aligned}
$$

Menentukan rute terpendek menggunakan Algoritma Dijkstraa

Perhitungan solusi optimal menggunakan model CGVRP dan Algoritma Dijkstraa dari model GVRP:

a. Penyelesaian pada kluster 1

Berdasarkan model GVRP diatas sudah dipilih titik awal pada kluster 1 yaitu vertek 29 .

$$
\begin{aligned}
& \mathrm{i}=v_{29}, v_{36}, v_{46}, v_{51}, v_{52} \\
& \mathrm{j}=v_{29}, v_{36}, v_{46}, v_{51}, v_{52} \\
& \begin{array}{lllll}
v_{29} & v_{36} & v_{46} & v_{51} & v_{52}
\end{array} \\
& \mathrm{~W}=\begin{array}{l}
v_{29} \\
v_{36} \\
v_{46} \\
v_{51} \\
v_{52}
\end{array}\left[\begin{array}{ccccc}
\infty & 1900 & 1000 & 4500 & 350 \\
1900 & \infty & 900 & 4100 & 1600 \\
1000 & 900 & \infty & 3500 & 650 \\
4500 & 4100 & 3500 & \infty & 3700 \\
350 & 1600 & 650 & 3700 & \infty
\end{array}\right]
\end{aligned}
$$

Berdasarakan data matrik tersebut selanjutnya melakukan itersi yang diilustrasikan dalam tabel 1 . 


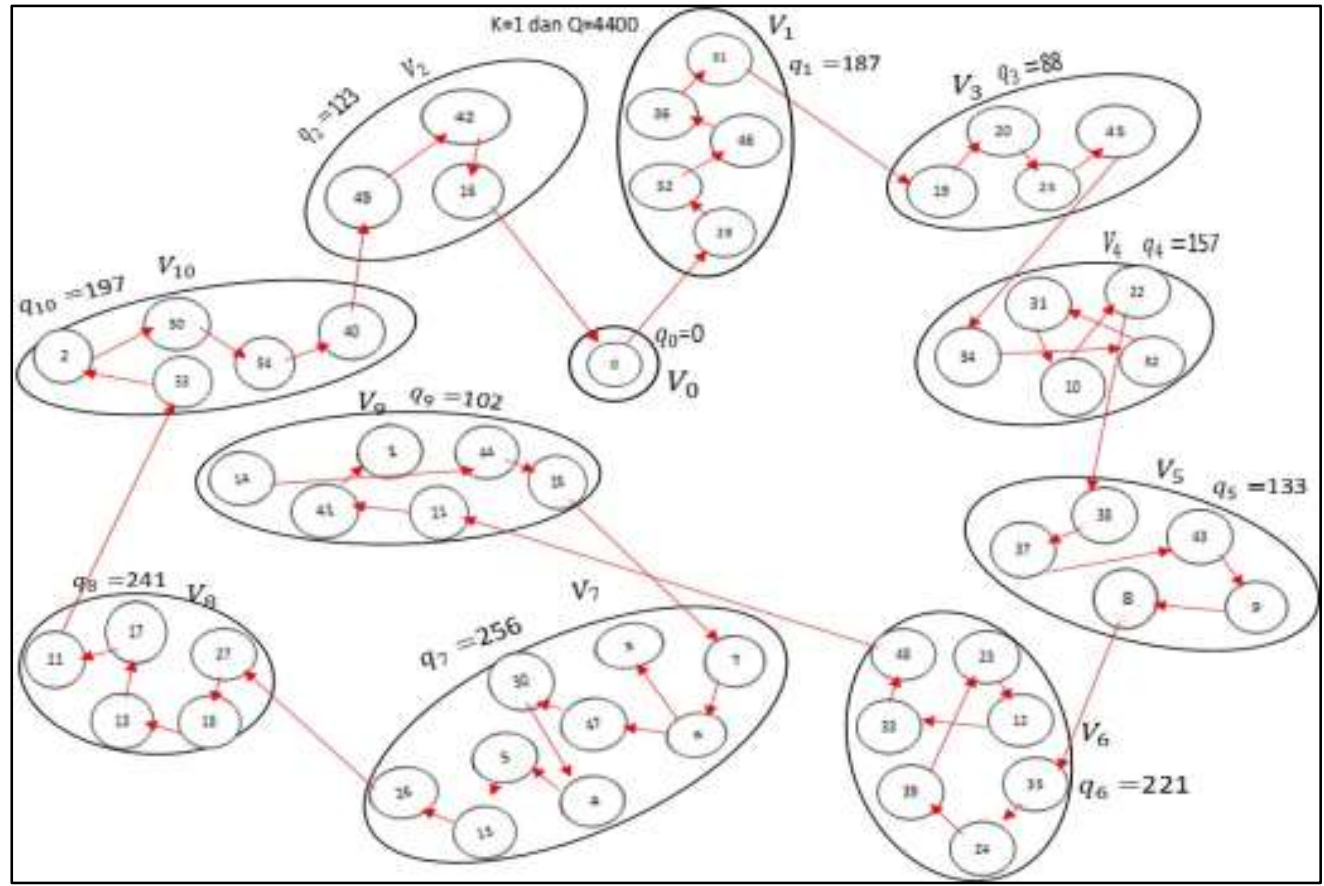

Gambar 4. Model CGVRP menggunakan perhitungan Algoritma Warshall

Tabel 1 Iterasi penyelesaian kluster 1

\begin{tabular}{|c|c|c|c|c|c|c|}
\hline $\mathrm{i}$ & $\mathrm{D}(29)$ & $\mathrm{D}(36)$ & $\mathrm{D}(46)$ & $\mathrm{D}(51)$ & $\mathrm{D}(52)$ & $\mathrm{L}$ \\
\hline 0 & 0 & $\infty$ & $\infty$ & $\infty$ & $\infty$ & $v_{29}$ \\
\hline 1 & - & $\operatorname{Min}\{\infty, 0+1900\}$ & $\operatorname{Min}\{\infty, 0+1000$ & $\operatorname{Min}\{\infty, 0+450$ & $\operatorname{Min}\{\infty, 0+350$ & $v_{29}, v_{52}$ \\
& & $=1900$ & \} & $0\}$ & \} & \\
& & & $=1000$ & $=4500$ & $=350$ & \\
\hline 2 & - & $\operatorname{Min}\{1900,350+$ & $\operatorname{Min}\{1000,350+$ & $\operatorname{Min}\{4500,350$ & - & $v_{29}, v_{52}, v_{46}$ \\
& & $1600\}$ & $650\}$ & $+3700\}$ & & \\
& & $=1900$ & $=1000$ & $=4050$ & & \\
\hline 3 & - & $\operatorname{Min}\{1900,1000$ & - & $\operatorname{Min}\{4050,100$ & - & $v_{29}, v_{52}, v_{46}$, \\
& & $+900\}$ & & $0+3500\}$ & & $v_{36}$ \\
& & $=1900$ & & $=4050$ & & \\
\hline 4 & - & - & - & $\operatorname{Min}\{4050,190$ & - & $v_{29}, v_{52}, v_{46}$, \\
& & & & $0+4100\}$ & & $v_{36}, v_{51}$ \\
& & & & $=4050$ & & \\
\hline
\end{tabular}

\section{Keterangan $=\square$ Rute Terpilih}

Berdasarkan tabel diatas diketahui rute terpendek $v_{29}-v_{52}-v_{46}-v_{36}-v_{51}$ dengan total jarak 6000 meter.

Setelah melakukan perhitungan dengan cara yang sama pada semua kluster didapatkan data dari perhitungan masing-masing kluster dengan menggunakan GVRP setelah itu mengunakan model CGVRP dalam menghitung didalam kluster dan untuk menentukan urutan vertek yang dilalui didalam kluster menggunakan Algoritma Dijkstraa didapatkan keselurahan rute terpendek yang digunakan dalam pendistribusian. Dengan rute terpendek sebagai berikut:

$$
\begin{aligned}
& v_{0}-v_{29^{-}}-v_{52^{-}}-v_{46^{-}}-v_{36^{-}} v_{51^{-}}-v_{19^{-}} v_{20^{-}}-v_{25^{-}}-v_{45^{-}}-v_{34^{-}} \\
& v_{32^{-}} v_{31^{-}}-v_{10^{-}}-v_{22^{-}}-v_{38^{-}}-v_{37^{-}}-v_{43^{-}}-v_{9^{-}}-v_{8^{-}}-v_{35^{-}}-v_{24^{-}} \\
& v_{39^{-}} v_{23^{-}}-v_{12^{-}} v_{33^{-}}-v_{48^{-}}-v_{21^{-}}-v_{41^{-}}-v_{1}-v_{14^{-}}-v_{44^{-}} v_{28^{-}} \\
& v_{7}-v_{6}-v_{3}-v_{47^{-}}-v_{30}-v_{4}-v_{5}-v_{15^{-}}-v_{26^{-}}
\end{aligned}
$$




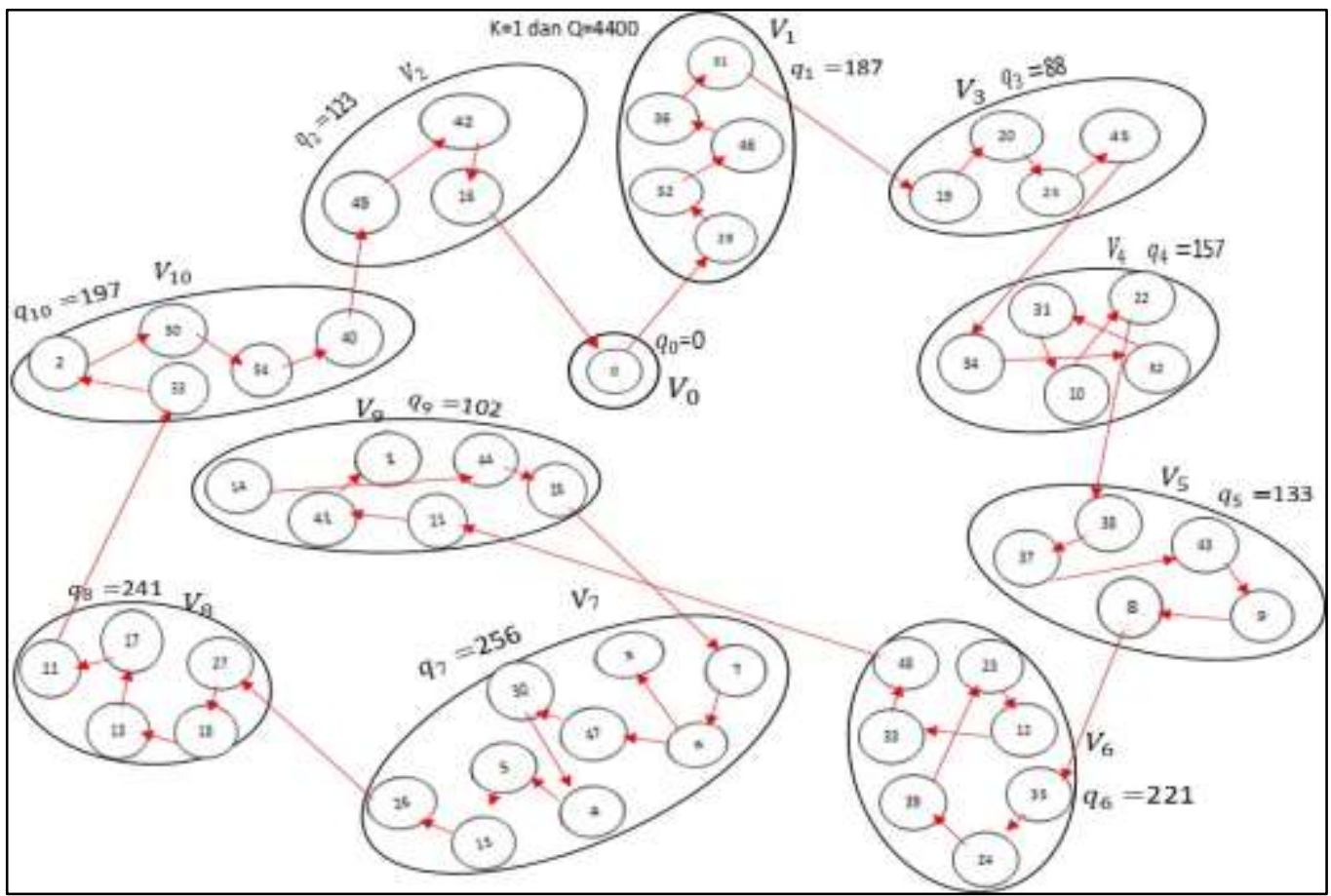

Gambar 5. Model CGVRP Perhitungan Algoritma Dijkstraa

$v_{27}, v_{18}, v_{13}, v_{17}, v_{11}-v_{53}-v_{2}-v_{50^{-}}-v_{54^{-}}-v_{40^{-}} v_{49^{-}}$ $v_{42}-v_{16}-v_{0}$ dengan total jarak sebesar 50200 meter.

Dari hasil perhitungan rute terpendek dapat di ilustrasikan pada gambar 5 .
Analisa Perbandingan Rute Terpendek Menggunakan Algoritma Warshall dan Algoritma Dijkstraa

Berdasarkan data hasil perhitungan yang telah dilakukan maka dapat menganalisis perbandingan rute terpendek menggunakan Algoritma Warshall dan Algoritma Dijkstraa dilihat pada tabel 2 sebagai berikut:

Tabel 2. Tabel Perbandingan Algoritma Warshall dan Dijkstraa

\begin{tabular}{|c|c|c|c|c|}
\hline \multirow[b]{2}{*}{ No } & \multirow[b]{2}{*}{ Perhitungan } & \multicolumn{3}{|c|}{ Perbandingan } \\
\hline & & Rute & $\begin{array}{c}\text { Total Jarak Tempuh } \\
\text { (Meter) }\end{array}$ & $\begin{array}{l}\text { Total Biaya } \\
\text { (RP) }\end{array}$ \\
\hline 1 & Algoritma Warshall & $\begin{array}{l}v_{0^{-}} v_{29^{-}} v_{52^{-}}-v_{46^{-}}-v_{36^{-}} v_{51^{-}} \\
v_{19^{-}} v_{20^{-}} v_{25^{-}} v_{45^{-}}-v_{34^{-}} \\
v_{32^{-}}-v_{31}-v_{10^{-}}-v_{22^{-}}-v_{38^{-}} \\
v_{37^{-}}-v_{43^{-}}-v_{9^{-}} v_{8^{-}} v_{35^{-}} v_{24^{-}} \\
v_{39^{-}} v_{12^{-}}-v_{33^{-}} v_{23^{-}} v_{48^{-}} \\
v_{21^{-}} v_{41^{-}}-v_{14^{-}} v_{1}-v_{44^{-}} v_{28^{-}} \\
v_{7^{-}} v_{6^{-}} v_{3^{-}} v_{47^{-}} v_{30^{-}} v_{4^{-}} \\
v_{5^{-}} v_{15^{-}} v_{26^{-}} \\
v_{27}, v_{18}, v_{13}, v_{17}, v_{11^{-}} v_{53^{-}} \\
v_{2^{-}} v_{50^{-}} v_{54^{-}} v_{40^{-}} v_{49^{-}} v_{42^{-}} \\
v_{16^{-}} v_{0}\end{array}$ & 49400 & 39.829-,. \\
\hline 2 & Algoritma Djistraa & $\begin{array}{l}v_{0^{-}} v_{29^{-}} v_{52^{-}} v_{46^{-}}-v_{36^{-}} v_{51^{-}} \\
v_{19^{-}} v_{20^{-}} v_{25^{-}} v_{45^{-}}-v_{34^{-}} \\
v_{32^{-}}-v_{31^{-}}-v_{10^{-}}-v_{22^{-}}-v_{38^{-}}\end{array}$ & 50200 & 40.474-,. \\
\hline
\end{tabular}




\begin{tabular}{|c|c|c|c|c|}
\hline \multirow[b]{2}{*}{ No } & \multirow[b]{2}{*}{ Perhitungan } & \multicolumn{3}{|c|}{ Perbandingan } \\
\hline & & Rute & $\begin{array}{c}\text { Total Jarak Tempuh } \\
\text { (Meter) }\end{array}$ & $\begin{array}{l}\text { Total Biaya } \\
\text { (RP) }\end{array}$ \\
\hline & & $\begin{array}{l}v_{37^{-}} v_{43^{-}}-v_{9^{-}} v_{8^{-}} v_{35^{-}} v_{24^{-}} \\
v_{39^{-}} v_{23^{-}}-v_{12^{-}} v_{33^{-}} v_{48^{-}} \\
v_{21^{-}}-v_{41^{-}}-v_{1^{-}} v_{14^{-}} v_{44^{-}} v_{28^{-}} \\
v_{7^{-}}-v_{6^{-}} v_{3^{-}}-v_{47^{-}}-v_{30^{-}} v_{4^{-}} \\
v_{5^{-}} v_{15^{-}} v_{26^{-}} \\
v_{27}, v_{18}, v_{13}, v_{17}, v_{11^{-}} v_{53^{-}} \\
v_{2^{-}} v_{50^{-}} v_{54^{-}} v_{40^{-}} v_{49^{-}} v_{42^{-}} \\
v_{16^{-}}-v_{0}\end{array}$ & & \\
\hline
\end{tabular}

Dari Tabel 2 dapat dianalisa bahwa Algoritma Warshall dan Dijkstraa untuk menentukan rute terpendek memiliki cara perhitungan dan hasil yang hampir sama dengan selisih total jarak 800 meter dengan selisih biaya Rp. 645. dalam sekali jalan. Perbedaan rute hanya berada pada kluster 6 dan kluster 9 .

\section{PENUTUP}

\section{Kesimpulan}

Berdasarkan penelitian yang telah dilakukan dapat diperoleh kesimpulan yang didasarkan atas rumusan masalah dan tujuan awal penelitian yaitu menganalisis penentuan Rute Terpendek dengan membandingkan Algoritma Warshall dan Dijkstraa pada metode GVRP. Perhitungan dengan menggunakan Algoritma Warshall didapatkan rute terpendek dengan total jarak optimal sebesar 49,4 km sehingga menghabiskan biaya bahan bakar sebesar Rp 39.829. Sedangkan perhitung rute terpendek menggunakan Algoritma Dijkstraa didapatkan rute terpendek dengan total jarak optimal sebesar 50,2 $\mathrm{km}$ yang memiliki biaya sebesar Rp 40.474. Jadi Algoritma Warshall dan Algoritma Dijkstraa memiliki cara perhitungan yang hampir sama dengan total jarak dan biaya memiliki selisih yang relatif kecil.

\section{REFERENSI}

Devo Avidianto P. (2010) Pengertian Distribusi dan Fungsi Distribusi. [Online].http://www.devoav1997.webnode.c om

Faisol, F \& Masdukil Makruf. 2017." Distribusi Batik Madura Melalui Penerapan Generalized Vehicle Routing Problem (GVRP)".Jurnal Matematika: Vol 3 No 2, 101-104.

Gautama, I. P. W., \& Hermanto, K. (2020).

Penentuan Rute Terpendek dengan Menggunakan Algoritma Dijkstra pada Jalur Bus Sekolah. Jurnal Matematika, 10(2), 116-
123.

https://doi.org/10.24843/JMAT.2020.v10.i02. p128

Hermanto, K., Adiasa, I., Altarisi, S., Rabani, R., \& Amirul, M. (2020). Rute Usulan Pendistribusian LPG Menggunakan Model Clustered Generalized Vehicle Routing Problem (CGVRP) dan Algoritma Dijkstra. Performa: Media Ilmiah Teknik Industri, 19(1), 27-36. https://doi.org/10.20961/performa.19.1.41858

Hermanto, K., \& Ermayanti, T. D. (2019). Analisa Optimasi Rute Transportasi Antar Jemput Siswa Menggunakan Model CGVRP dan Algoritma Dijkstra di SDIT Darus Sunnah. Jurnal UJMC, 5(2), 19-28. http://ejurnal.unisda.ac.id/index.php/ujmc/article/vie w/1653

Hermanto, K., \& Ruskartina, E. (2018a). Optimasi Rute Truk Pengangkut Sampah di Kota Sumbawa Besar Shift II Menggunakan GVRP. Jurnal UJMC, 4(2), 15-23.

Hermanto, K., \& Ruskartina, E. (2018b). Usulan Rute Optimal Distribusi Sampah Shift I Kota Sumbawa Besar Menggunakan Metode GVRP. Eigen Mathematics Journal, 01(02), 7-12.

Hermanto, Koko.2015. 'Model Matematika Generalized Vehicle Routing Problem Dan Ekstensinya Studi Kasus: Pendistribusian Kertas Karton. Tesis. Universitas Gajdah Mada.

Indroyono Gitosudarmono, Manajemen Pemasaran. Yogyakarta: BPEE, 2000.

Irwan Iftadi, Wakhid Ahmad Jauhari, dan Beny Nugroho. "Perancangan Peta Evakuasi Menggunakan Algoritma Floyd-Warshall untuk Penentuan Lintasan Terpendek: Studi Kasus".Makalah.2011.

Jayanti, Ni Ketut Dewi Ari. 2014.” Penggunaan Algoritma Floyd Warshall Dalam Masalah Jalur Terpendek Pada Penentuan Tata Letak Parkir”.STIMIK STIKOM Bali. Bali.

Maulidya, R dan Kusuma ningrum. 2013.’Perbaikan Sistem Distribusi dan 
Tranportasi dengan menggunakan distribution requitment planning $(D R P)$ dan Algoritma Djikstra”. Studi kasus : Depot Pertamina Tasikmalaya. Jurnal Teknik industry,pp ISSN.

Hamin, Ismaillia Nur. (2017).Identifikasi Alternatif Pengadaan Bahan Baku di PDAM Kabupaten Boyolali.

[Online].http://www.etd.eprints.ums.ac.id/ 1743

Saputra, Ragil. 2011." Sistem Informasi Geografis Pencarian Rute Optimum Obyek Wisata Kota Yogyakarta Dengan Algoritma FloydWarshall”.Matematika, Vol 14. No 1: Jurnal Matematika.
Sari, Pipit.2017.” Metode Vehicle Routing Problem (Vrp) Dalam Mengoptimalisasikan Rute Distribusi Air Minum PT.Smu".Jurnal SemNas:147-153.

Siang,Jong Jek.2014.'Riset Operasi dalam pendekatan Algoritmis". Yogyakarta: Andi Offset.

Tramizi. 2005."Optimasi usaha Tani dalam Pemanfaatan Air Irigasi Embung Leubuk Aceh besar," Jurnal Teknik Pertanian. 